Bond University

Research Repository

\title{
The value of built heritage
}

\section{Community, economy and environment}

Irons, Janine; Armitage, Lynne

Published in:

Pacific Rim Property Research Journal

DOI:

10.1080/14445921.2011.11104345

Licence:

Other

Link to output in Bond University research repository.

Recommended citation(APA):

Irons, J., \& Armitage, L. (2011). The value of built heritage: Community, economy and environment. Pacific Rim Property Research Journal, 17(4), 614-633. https://doi.org/10.1080/14445921.2011.11104345

\footnotetext{
General rights

Copyright and moral rights for the publications made accessible in the public portal are retained by the authors and/or other copyright owners and it is a condition of accessing publications that users recognise and abide by the legal requirements associated with these rights.
}

For more information, or if you believe that this document breaches copyright, please contact the Bond University research repository coordinator. 


\title{
The value of built heritage: Community, economy and environment
}

\author{
Janine Irons, Curtin Business School, Curtin University, Perth \\ and \\ Lynne Armitage, Institute of Sustainable Development and Architecture \\ Bond University, Queensland \\ Lynne_Armitage@bond.edu.au (corresponding author)
}

\begin{abstract}
Whilst legislatures at all levels of Australian government have been slower to establish heritage protection than many other OECD countries, the community's commitment predates identifiable involvement by government in the conservation arena by more than two decades as illustrated by the foundation, in Sydney in the mid 1940's, of the National Trust of Australia (AGPC 2006). It was not until the 1970's that formal frameworks were established through statutory control mechanisms for the identification and protection of Australia's rich stock of heritage places (Irons and Armitage 2010). Similarly, at the professional level, the relatively recent emergence and dissemination of standardised approaches to valuation and management practices for heritage property (e.g. IVSC 2007; API 2008; RICS 2009) across international boundaries is an acknowledgement of their special value and - to some extent - demonstrates a recognition of characteristics which are shared by diverse cultures (Armitage and Yau 2008).
\end{abstract}

Set within the context of Australia's commitment to the Kyoto protocols, requiring signatory countries to meet mandated reductions in the use of non-renewable resources, the potential opportunity cost savings achievable by the more effective use of existing built structures has re-emerged as an area of interest. The objective of this paper is to review the multifaceted elements which contribute to our perceptions of heritage reflecting values which incorporate yet transcend the merely economic (Ashworth 2002) within this contemporary perspective of the role of heritage property identified above. This paper draws upon a rigorous study (Irons 2008) which investigates in detail the effect of local heritage listing on the single family dwelling. The paper identifies the framework of heritage management in Australia and considers the many meanings of the relevant terminology. Concepts of cultural heritage, of place and of significance are discussed providing a preface to a review of the value of heritage from a number of perspectives. In an age of increased sensitivity to profligate resource consumption, this traditional view is then extended to consider the potential environmental benefits of heritage conservation, contributing a contemporary commentary to some economic, social and professional concerns and reflects upon the challenges of the journey yet to come.

Keywords: Australia; built heritage; heritage and environment; heritage significance; heritage value; property value. 


\section{Introduction}

Set within the context of Australia's commitment to the Kyoto protocols, requiring signatory countries to meet mandated reductions in use of non-renewable resources, the opportunity cost savings potentially achievable from the more effective use of existing built structures have re-emerged as an area of interest. The objective of this paper is to review the multifaceted elements which contribute to our perceptions of the value of heritage which incorporate yet transcend the merely economic (Ashworth 2002) within this contemporary perspective of the role of heritage property identified above. This paper draws upon a rigorous empirical study (Irons 2008) which investigates in detail the effect of local heritage listing on the single family dwelling. After discussing some general principles of conservation and management, and considering the often competing arguments of preservation and conservation, some of the many meanings of the term heritage, concepts of cultural heritage, of place and of significance, are defined. The section following then identifies a range of potential benefits of heritage conservation, contributing a contemporary commentary to elements of economic, social and professional concerns in an age of increased sensitivity to profligate resource consumption and reflects upon the challenges of the journey yet to come.

\section{Managing heritage: What do we mean by heritage?}

Gazetted in 1975, the Australian Heritage Commission Act (AHC Act) initiated the heritage legislative system at the national level and whilst this statute has been superseded, subsequent legislation has reaffirmed the tenets of the Act. The Environment Protection and Biodiversity Conservation Act 1999 (Cth) (EPBC Act), for example, provides a more contemporary reinterpretation of the original definition offered by the AHC Act. Section 528 of the EPBC Act defines the heritage value of a place as including the 'place's natural and cultural environment having aesthetic, historic, scientific or social significance, or other significance, for current and future generations of Australians'. The EPBC Act also provides for a formal broadening in Australia's heritage focus and offers a more appropriate and inclusive contemporary interpretation of heritage with Indigenous heritage value being specifically referenced and defined within the EPBC Act.

For the purposes of the EPBC Act, environment includes the 'heritage values of places' (s. 528). As such, heritage, or more precisely heritage value is formally recognised as comprising a component part of the environment. A common misconception, rooted in the origins of heritage conservation practice, is that the terms heritage and historic are synonymous. This has the effect that 'heritage means old' and results in a mistaken interpretation all too often adopted. 
When discussing the development of the heritage frameworks in Australia, the role of the Burra Charter (Australia ICOMOS 1999) must be recognised as an authority. It is an internationally recognised guiding document that defines the basic principles, processes and practices to be followed in the conservation of Australia's heritage places. The Burra Charter is widely accepted and adopted as the standard for best practice in the heritage and conservation fields. The principles and definitions contained within the Charter have been very influential in framing Australia's system of heritage conservation. In particular, much of the heritage legislation enacted at federal and state government levels is written in the spirit of the Charter and much of the content of the statutes closely mirrors the definitions and guidelines laid down within the Charter. (Adapted from: HCWA 2005)

Aplin (2002) discusses some general principles of conservation and management, drawing on both the Burra Charter and on various statutory definitions, defining conservation at page 69 as

- all the processes of looking after a place so as to retain its cultural significance ... including maintenance and may according to circumstances include preservation, restoration, reconstruction and adaptation ... commonly a combination of more than one of these.

As such it is viewed as the 'overall process of caring' in order to retain significance which may require varying degrees of intervention for natural as opposed to built heritage with the latter being likely to be protected from the effects of aging by physical maintenance and replacement and management strategies for continuing occupation and use where this contributes to the significance of the place, as is frequently the case for places of cultural significance.

Preservation is defined by Aplin (2002:71) as 'maintaining the fabric of a place in its existing state and retarding deterioration.' Preservation is again closely linked to maintenance but the extent of intervention may be not merely restricted to keeping the fabric in good condition but to actively engage in avoiding damage or further deterioration. Whilst this would not extend to remedying prior deterioration - which would amount to restoration - a focus on damage limitation could result in the withdrawal of access rights to the public which can result, when applied insensitively, in community outrage. In practice such draconian measures tend to be restricted to situations of self-evident need and applied in only the most extreme of circumstances.

Whilst early conservation efforts focused almost exclusively on the protection of old buildings, heritage - within a contemporary context - has evolved to represent a far more inclusive construct. This focus is notable in the definition offered under the EPBC Act, which specifies a place may assume heritage value not solely as a result of its historic significance but also of its aesthetic, scientific or social significance. Thus, whilst the passage of time may once have served as the primary qualifier upon 
which heritage significance was judged during the early periods of heritage conservation practice, this is no longer the case. The heritage significance once endowed by the passage of time has developed into significance that embraces heritage value as a far more liberal measure, embracing the aesthetic, scientific or social aspects of significance. This might, for example, include modern architectural worth or the associative heritage meaning of a recently constructed building. Defining heritage value in such terms admits the importance the recent past may hold within a heritage context and recognises vintage as but one qualifier amongst many.

In a similar vein, the heritage significance of an item is held to include:

[a]ll the values that make it special to past, present and future generations. These may be its historical origins and subsequent development, its association with particular people or events, its visual or townscape qualities, its construction or other technical qualities, a religious or symbolic role and archaeological research potential. The values may not only be evident in the fabric or physical material of the place, building, work, relic, movable object or precinct, but also in the relationship with its surroundings, and in associated documents that can be researched to gain knowledge of the item and its significance. The values do not have to be mutually exclusive and usually a place will have multiple values. The values of an item will depend on its integrity, comparative standing, and community perceptions

NSW Heritage Office 2002, s. 2.3

The term significance is used to describe an item's heritage value and, in doing so, it serves to establish the importance of an item within a heritage context. Heritage significance has come to represent a basic tenet of conservation policy and practice. The concept has been widely embraced by all levels of government in Australia, with definitions of significance and associated criteria for its assessment featuring prominently in the legislative landscape. Heritage significance has provided a consistent and uniting point of reference in the development of Australia's heritage conservation agenda for well over a decade - serving as an important vehicle by which to establish benchmarks for recognising and managing Australia's heritage resources as social values continue to evolve.

The notion of significance is so closely interlinked with that of value that the two terms may often be used interchangeably. For example, the Australia International Council on Monuments and Sites (ICOMOS) Charter for Places of Cultural Significance (the Burra Charter) defines cultural significance as meaning 'the aesthetic, historic, scientific, social or spiritual value for past, present or future generations'. (Australia ICOMOS 1999:2) Here it can be seen that the definition closely mirrors that provided in the EPBC Act, with the terms value and significance simply exchanged. Australia ICOMOS has in fact acknowledged the substitutability of these terms: 
[w]ith regard to the term 'significant', this term has had a long history of use in Australia, dating back to at least the 1970s. 'Significance' is synonymous with value, and is shorthand for cultural or heritage significance and cultural or heritage value. In general contexts, significance merely denotes some level of heritage value. In statutory contexts, it can mean that a certain level of value has been identified.

(EBPC Act sub. 122, p. 100, cited in AGPC 2006, s. 2, p. 12)

\section{The importance of heritage: The broad view}

Why is heritage important? The straightforward answer to this complex and multi-dimensional question is simply that heritage is important because it is considered to be so by the people of Australia (AGPC 2006). In respect of heritage places, their importance is seen to lie in the values or benefits they produce (AGPC 2006). Thus, it can be seen that importance stems from the values or benefits that heritage places are capable of delivering, both to individuals and, collectively, to society as a whole.

Importance may manifest itself in various ways. For example, it may be a product of direct tangible benefits such as the economic benefits that flow from heritage tourism or it may flow from indirect and/or intangible benefits whether cultural, social, educational, aesthetic or spiritual in nature. These may be represented by the pleasure an individual derives from the aesthetic qualities of a heritage place or by the sense of identity, belonging and connection that heritage places may promote within a community. These benefits may also be further distinguished on the basis of use and non-use values. The former relate to direct benefits, both tangible and intangible, received through use of a heritage place and would include both economic benefits and aesthetic benefits. In contrast, non-use value which can also be referred to as passive use value - arises in the absence of direct consumption as individuals may derive value from a heritage place without ever physically viewing or entering the place but by association or reflection. Examples of such benefits include option value, existence value and bequest value as expanded in Table 1: 'Potential benefits of heritage conservation'.

In Australia, the importance placed by individuals on heritage conservation was highlighted in a large scale nationwide survey undertaken by Allen in 2005. Table 2: 'Community views and perceptions of heritage-related values' summarises a number of key results from that study. The results of Allen's research elicit a number of interesting points. The high level of agreement across all areas of enquiry is particularly noteworthy with, for example, 92 per cent of respondents strongly agreeing or agreeing with the statement that heritage forms part of Australia's identity. Similarly, at 87.1 per cent, respondents were overwhelmingly in support of the view that heritage plays an important part in Australia's culture. 
Table 1 Potential benefits of heritage conservation

\begin{tabular}{l}
\hline Owner Benefits \\
- Aesthetic benefits \\
- Use benefits e.g. as a place of residence, work, etc. \\
- Amenity benefits \\
- Economic/financial benefits \\
Community benefits \\
- The role of the historic heritage place in defining the cultural identity of \\
- Contribution to the preservation of community heritage. \\
- Contribution to historic streetscape, neighbourhoods etc. \\
- Educational benefits. \\
- Spill-over benefits from tourism. \\
- Option values - the value to community members of having the option \\
to visit the historic heritage place in the future. \\
- Bequest values - the value associated with the knowledge that the heritage \\
asset can be endowed to future generations. \\
- Existence values - the benefits gained from knowing that the historic heritage \\
the benefit of actually visiting it. \\
\hline
\end{tabular}

Source: adapted from AGPC 2006:14

In fact, whether framed within a local or national context, high levels of agreement were evident for all statements relating to the role and importance of heritage in relation to culture, identity and the character of the environment. Heritage education was also considered very important, recording the highest level of agreement of all the response categories at virtually 97 per cent. A preference for heritage features being retained as part of the dynamic urban environment was also strongly supported with almost 95 per cent of respondents agreeing or strongly agreeing, a sentiment which indicates people's preference for maintaining continuity amidst change which was a view supported by the similar level of strong support (at 87 per cent) to the complementary question of keeping heritage places 
and providing for the needs of today. Interestingly, however, just over half the respondents surveyed agreed that heritage protection plays an important role in the economy. Given that perhaps the most tangible, direct and quantifiable benefit of heritage conservation may flow from its contribution to the economy (e.g. heritage tourism) it is somewhat surprising that a higher level of importance was not associated with this statement and may indicate that the potential economic benefits associated with heritage conservation are generally not well recognised or understood within the community at large.

Table 2: Community views and perceptions of heritage-related values

\begin{tabular}{|c|c|c|c|}
\hline $\begin{array}{l}\text { Level of Agreement with Statement } \\
\text { (per cent) }\end{array}$ & $\begin{array}{c}\text { Strongly } \\
\text { Agree } \\
\text { and Agree }\end{array}$ & $\begin{array}{c}\text { Strongly } \\
\text { Disagree } \\
\text { and Disagree }\end{array}$ & $\begin{array}{c}\text { Neither } \\
\text { Agree } \\
\text { nor } \\
\text { Disagree }\end{array}$ \\
\hline Heritage is a part of Australia's identity & 92.3 & 2.3 & 5.3 \\
\hline $\begin{array}{l}\text { Heritage plays an important part in Australia's } \\
\text { culture }\end{array}$ & 87.1 & 3.5 & 9.4 \\
\hline Celebrating heritage is important & 81.5 & 2.3 & 16.3 \\
\hline $\begin{array}{l}\text { It is important to keep historic features wherever } \\
\text { possible when trying to improve towns and cities }\end{array}$ & 94.7 & 1.1 & 4.2 \\
\hline $\begin{array}{l}\text { The historic buildings in my local area are worth saving and } \\
\text { are important parts of heritage }\end{array}$ & 84.1 & 3.4 & 12.5 \\
\hline $\begin{array}{l}\text { The historic houses in my local area are an important part } \\
\text { of the area's character and identity }\end{array}$ & 80.2 & 5.2 & 14.5 \\
\hline $\begin{array}{l}\text { Looking after our heritage is important in creating jobs and } \\
\text { boosting the economy }\end{array}$ & 56.1 & 11.0 & 32.9 \\
\hline $\begin{array}{l}\text { It is important to protect heritage places even though I may } \\
\text { never visit them }\end{array}$ & 93.4 & 1.5 & 5.0 \\
\hline We protect too much heritage & 9.0 & 69.4 & 21.7 \\
\hline $\begin{array}{l}\text { It is possible to keep heritage places and provide for the } \\
\text { needs of today }\end{array}$ & 86.7 & 3.2 & 10.1 \\
\hline $\begin{array}{l}\text { My life is richer for having the opportunity to visit or } \\
\text { see heritage }\end{array}$ & 78.7 & 4.6 & 16.8 \\
\hline It is important to educate children about heritage & 96.9 & 0.3 & 2.8 \\
\hline
\end{tabular}

Source: Adapted from Allen, 2005, pg. 71. 
The strong parallels between the results of the AGPC 2006 research into heritage conservation's benefits and the work of Allen are evident, confirming the strength of people's views with support for heritage identity, culture and education featuring prominently and, together with economic benefits and option value, embraced as a part of everyday life,. A further indication that people hold heritage to be important is the very existence of formal systems of heritage recognition and management. This is achieved on several levels across the Australian community both through the many volunteer bodies with nationwide membership - such as the National Trust - as well as by local heritage or historic societies demonstrating that individuals (and hence collectively, society) recognise the importance of heritage and consequently seek its conservation which the legislative structures then formally enshrine.

A number of economic perspectives on the value of heritage are expanded in the following section.

\section{The importance of heritage: The economic perspective}

Brown (2004) identifies the primary components of the economic effect of heritage conservation as including:

1. the impact of building work itself

2. heritage tourism, and

3. the impact of heritage designation on property values.

In Australia, the economic benefits capable of flowing from heritage protection are recognised by governments at all levels. For example, the 2007 State of the Environment Report released by the Environmental Protection Authority of Western Australia (EPAWA) notes that:

[h] eritage conservation can aid economic prosperity by contributing to the attractiveness of the living and working environment, by stimulating and supporting tourism and by encouraging economic diversification and investment in a locality or region.

EPAWA, 2007:12

In addition, the higher economic returns that may be generated often benefit local communities more directly than is the case with non-heritage related building activity. Brown (2004) suggests that the labour intensity of new construction is on average 50 per cent labour and 50 per cent materials, whereas building works associated with heritage properties (renovation, repairs, maintenance, additions, etc.) on average comprise approximately a 70 per cent labour component and a 30 per cent materials component. Rypkema (2005) similarly concluded that between 60 to 70 per cent of the cost of heritage renovation works goes toward labour, compared to about 50 per cent for new construction activities. 
The relative benefits of the larger labour component are also reflecting the reduced consumption of materials and not only the higher unit cost of the often specialist labour skills which heritage property necessitates. The aspect of more prudent consumption of scarce resources is considered further in the final section of this paper (Section 6).

Brown also identifies heritage tourism as a key economic effect of heritage conservation and the economic value of heritage tourism in Australia has long been acknowledged (AGPC 2006). Research indicates that the heritage tourism sector is the fastest growing and highest yielding sector of the tourism market, with heritage tourism creating a proportionately higher return than other forms of tourism as visitors tend to stay longer and spend more (InterSector 2006). The ABS (2009) reports that heritage buildings, sites or monuments had the highest rate of attendance by international cultural and heritage visitors at 61 per cent, followed by visits to museums and art galleries at 57 per cent. Data for domestic cultural tourism for that period (ABS 2009a) reports the most popular cultural activity as visits to museums and art galleries at 44 per cent (overnight visitors) and 35 per cent (day visitors) with historic/heritage buildings, sites or monuments attracting 30 per cent and 24 per cent of overnight and day visits respectively. This represented (domestic data) some 14 per cent (9.7 million) cultural and heritage visits totalling 54 million nights away, confirming Brown's observations of the economic significance of heritage as a strong economic driver.

The third and final economic effect highlighted by Brown relates to the impact of heritage listing on property values. Although, in Australia, the community's support for heritage protection is well embedded in the culture, the policies and practices employed in advancing the conservation agenda have long been the subject of public discourse and debate (AGPC 2006). Argument has largely centred on the question of what constitutes an appropriate balance between heritage controls and the rights of land owners, a question which clearly possesses strong equity dimensions and one to which vastly differing (and oftentimes emotive) responses have emerged from different sectors of the community. One of the considerations which lies at the very heart of this issue is the concerns of land owners who fear that any diminution in property rights associated with the application of heritage controls will invariably result in a loss in property value - an argument that finds strong support in economic theory (Asabere and Huffman 1994; Coulson and Lahr 2005; Clark and Herrin 1997; Deodhar 2004; Ford 1989; Irons 2008; Shipley 2000). It is here, at the property rights/property value interface, that debate often centres in practice as well as in theory.

The debate surrounding the impact of listing on property values introduced above notes that researchers are divided regarding the economic impact. Several Australasian empirical studies (Abelson 2001; Dominy 2001; Irons 2008; Nahkies 2002) suggest that heritage designation may exert a positive, neutral or negative influence on residential property values. However, the weight of the extant research would 
tend to suggest that listing is more likely to produce a positive or neutral pricing affect than a negative one and, with increasing recognition of the benefits of more environmentally sustainable practices, one which is likely to find increasing support within the community, government and corporate sector and is discussed further in Section 6 hereunder.

It can be seen from the above discussion that heritage conservation is capable of producing wideranging economic impacts. These impacts may be positive or negative in nature and, in some cases, both, depending on the specifics of context, perspective or circumstance applied.

\section{Market and heritage value: the professional perspective}

The ordinarily accepted definition of market value, as laid down by the International Valuation Standards Committee (IVSC) and adopted by the Australian Property Institute states that market value is

[t]he estimated amount for which a property should exchange on the date of valuation between a willing buyer and a willing seller in an arm's-length transaction after proper marketing wherein the parties had each acted knowledgeably, prudently and without compulsion.

Source: IVSC 2007:32

Extending now the focus on value to specifically address this concept from a heritage perspective, the value of heritage places is a distinctly more multifaceted and complicated construct than that associated with most ordinary economic goods. Its meaning is far more difficult to establish and its quantification is far more difficult to reconcile. Ashworth notes that:

\footnotetext{
[t]he value of heritage is more complex than that for most goods and services in that demand cannot be equated only with direct consumption. Heritage acquires value in a number of different ways that in turn determine how this value can be measured through price. Much heritage is produced to satisfy deferred, option, existence or bequest demands. The pricing of heritage and thus the price of a building or a heritage town could be calculated by determining the aggregate of the prices of direct and indirect use, existence, option and bequest values (Ashworth 2002:12)
}

From a practice perspective, the International Valuation Standards Council in 2007 demonstrated leadership in the field when it released Guidance Note 15 - the Valuation of Historic Property - which is incorporated within the API Valuation and Property Standards (2008) in its entirety (6.15.1-4). The guidance note provides an introduction to the nature of the asset which includes recognition of the impact of highest and best use (at 6.15.1.1.6): 
The assessment of highest and best use of historic properties will depend on the specific restrictions that apply to them. In some situations, the use of historic properties is limited to restoration for non-commercial use whilst in others, adaptation to some other use, including commercial use, is permissible.

Guidance note 15 (GN 15) continues with a discussion of scope focussing on historic buildings and sites and specifically excluding natural heritage and personal property; public and private property are both included recognising the commonality of their restoration, use or adaptability but also the potential for divergence in their statutory context; the discussion of scope concludes with comment on the breadth of property type which historic property encompasses but that all can be recognised as having 'historic character to some degree or other.' The guidance note also cites definitions of historic house owner associations, historic property, listing and a number of others are given as well as some drawn from the International Public Sector Accounting Standards Definitions (heritage asset is defined), UNESCO Glossary of World Heritage Terms (cultural heritage is defined) and World Heritage Convention, Article 1, UNESCO, 1972 (cultural property). (IVSC 2007)

The relationship of Guidance Note 15 to International Public Sector Accounting Standard 17 (Property, Plant and Equipment) is highlighted before the Section 5 of GN 15 details the valuation guidance aspects of the property's age, role of sales comparison, cost and income methods of valuation and the exhortation that 'comparability' should be sought from similarly characterised (historic) property with the recognition that 'many adjustments' may need to be made. Historic property in a commercial use, when valued using an income approach, is required to address any restoration works, zoning variations and additional maintenance liabilities due to the character of the building and its functional obsolescence. The guidance note also recognises (5.3) that some properties may have no potential for generating income or any relevant evidence of comparable sales and that legal measures to safeguard the character of the historic property may influence highest and best use and should be appropriately considered in the valuation process.

Valuing Heritage Assets (RICS 2009) looks at issues surrounding the valuation of heritage from an asset balance sheet and valuation perspective. It draws attention to the shortcomings of both a market and cost approach which arise frequently in the case of heritage property and give rise to consideration of the need for recognition and acceptance of alternative, non-market methodologies. These may include cost benefit analysis or willingness to pay or, where non-recognition approach to heritage assets is adopted, the use of shadow accounting. The aim is to ensure owners and other stakeholders are better informed as to the worth of their assets and that stewardship considerations are given due acknowledgement. This RICS report contains a useful bibliography for interested researchers. 
Whilst acknowledging that many different 'values' may attach to items regarded as possessing heritage value, all of which are important in their own right, the focus of this research rests firmly on the concept of market value.

It can be seen that the primary question to be addressed is the value affect of designation itself. Heritage listing is essentially akin to property zoning. Heritage controls place limits on property rights, particularly in relation to development rights. Opponents hold that, as listing places constraints on the bundle of property rights owners would otherwise have enjoyed, heritage listing exerts downward pressure of property prices (Brown 2004). Addressing this argument from an economic perspective, Ashworth (2002) argues that economic logic dictates that listing will lead to lower values - designation represents a constraint on the use of heritage places and thus a lessening of their utility and exchange value, listing a place simply renders it less usable and thus less valuable. Scanlon, Edge and Willmott (1994) note, not unsurprisingly, that the most striking instances of value loss tend to arise where heritage listing has either limited or altogether removed development opportunities that could, in the absence of heritage controls, be realised by the land owner. Thus, the more pronounced the opportunity cost of foregone development opportunities the more deleterious the impact of listing on property value. The AGPC (2006) highlights that heritage controls may also place owners in a position where they are forced to accept compromises to contemporary use and enjoyment, which again undermines utility and hence value.

From the above discussion it can be seen that control measures imposed through heritage listing serve to place encumbrances on the bundle of rights usually associated with real property ownership and therefore, economic theory dictates, should lower property value. Paradoxically, conservation proponents argue that heritage listing in fact produces quite the opposite effect, suggesting that increased property values are the natural consequence of the listing process. The argument advanced from this perspective centres on the positive pricing influence that may flow from the perceived benefits associated with ownership of a heritage listed property or from actual positive externalities associated with the protection listing provides. The latter may stem from various sources. For example, listing can provide owners with greater certainty and stability and offer more extensive and effective amenity value protection ranging across a variety of factors including aesthetic considerations and streetscape considerations) (Coulson and Lahr 2005). Such forces are capable of bringing positive pricing pressures to bear and consequently may result in listed property transacting at a premium in the marketplace (Asabere and Huffman 1994; Clark and Herrin 1997; Deodhar 2004; Ford 1989).

Quigley (1987) conducted a survey of owners of heritage properties identified in the South Australian City of Adelaide Heritage Register. Eighty per cent of respondents who had purchased their property before heritage controls had been introduced believed that listing had impacted the value of their 
property. The respondents were roughly evenly split between those who were unsure about the nature of the influence, those who thought it had been positive and those who believed it was negative.

A number of studies have concluded that heritage listed properties and properties located within heritage precincts generally sell for a premium compared to similar, non-listed properties (Clark and Herrin 1997; Asabere and Huffman 1994; Ford 1989). However, as already discussed, a body of studies also exists indicating that heritage designation may result in a decline in the sales price of listed properties (Asabere et al. 1994). To further complicate matters, research suggests that the impact of designation on property price may be a function of the nature of the listing imposed. For example, Schaeffer and Millerick (1991) found that national designation exerted a positive impact on property values whilst a negative pricing affect was associated with local designation. The authors suggest that the variance arises as a direct result of stronger (more restrictive) planning controls in place at a local level and from the prestige associated with ownership of a nationally recognised heritage property.

In a similar vein, there is also evidence to suggest that pricing affects may vary on the basis of socioeconomic characteristics, with listing more likely to exert a positive influence on price within affluent suburbs (AGPC 2006). It is possible that particular segments of the market identify listing as being associated with certain elements of status, prestige and image that some purchasers may consider in their decision making process. Market participants who control greater economic resources may attach more importance to these factors, with the result that they are willing (and able) to pay a premium to secure properties that possess these qualities.

So, in essence, heritage listing could be thought of as being akin to a luxury good, with more being spent on it as income rises. Although currently only an assertive presumption, as society becomes more sensitive to the negative impacts of excessive consumption, further status may attach to owners of heritage property when it can be demonstrated that their premises are less profligate in resource usage. It is this environmentally responsible perspective of heritage which will be considered in the section which follows.

\section{The importance of heritage: the environmental view}

At the time of writing (October 2010), the Australian government is still wrestling with the choice between a carbon tax and carbon trading options. When the surveys of public sentiment regarding the benefits to be derived from heritage conservation were undertaken by Allen and the Productivity Commission (AGPC), in 2005 and 2006 respectively, public awareness of global warming, the excessive use of resources leading to atmospheric pollution and any discussion of policies to reduce carbon and associated emissions were sentiments even less well developed. None of the formative 
materials - such as the UK government's Stern Review (2006), the Garnaut Review (2008) nor Al Gore's (Vice President of the United States) 2006 film 'An inconvenient truth' - which have since provided thought leadership and contributed to the community psyche were then in the effective public domain.

More specifically from a broad property perspective but not with heritage property in mind, Dixon (2009), discusses sustainability, corporate property and business practice. The study reflects the corporate real estate (CRE) view on responsibilities encumbent on corporate owners under UK legislation to meet corporate social responsibility (CSR) compliance. Given that a substantial number of heritage listed properties are held in corporate, public or private sector ownership, the adoption of practices which embed reduced energy demand (such as, for example, improvements in waste and water management and recycling, green procurement) and the adoption of more focussed facilities management practice will contribute to a reduction in carbon pollution.

Dixon (2009:13) gives some consideration of the role of adaptive reuse, refurbishment or retrofitting of existing premises which is an area where heritage property offers a unique and substantial opportunity. Practical illustration is provided by The Carbon Trust's (2008) study into the low carbon refurbishment of operating buildings which details case studies of successful carbon reduction strategies through the life cycle of the built asset from inception to redevelopment. The study notes that refurbishment and adaptive reuse are both effective carbon minimisation options.

Probably one of the most pertinent, and contemporary, discussions of the relationship between heritage conservation and sustainability is Horrigan's (2009) empirical study which considers a range of international approaches to policy from government and non-government/community organisation perspectives. Part of this study also looked at the impact of green rating metrics as applied to the built heritage asset. Horrigan opined that whilst the environmental merit of retaining and conserving heritage buildings is self-evident, data to support this assertion is sparse and, that although some indicators are being adopted for use with commercial property, their application to heritage property is not yet well developed - a trait which is characterised as frequently lacking in the field of heritage management.

Horrigan's investigations also highlighted that the attributes which are fundamental to this class of property - durability, embodied energy and life cycle elements - are not well recognised in the existing measurement tools' ratings. Furthermore, the more elusive aspects of heritage property's value to the community, such as its social and cultural contribution, are notably embarrassing by their absence. The total environmental cost and benefit of redevelopment and demolition versus retention and retrofit is also an equation which is apparently too difficult to imagine, specify and hence evaluate. The exclusion 
of the aesthetic in favour of the metric can only fuel the demolition option in more situations than would be warranted by a more liberal interpretation of the relative merits of these oft competing value systems - commerce and community.

It may yet again fall to the community sector to show leadership to government to raise awareness by action at grass roots level to reform particular aspects of the assessment of sustainability in the built environment. In Europe, there is a far larger stock of heritage property as a total of built assets and proportionally more heritage-related community organisations to provide a platform for political lobbying and for example, the UK is much further advanced in its reform of its heritage protection system. Horrigan's study indicates that the role of building regulation, of research and the performance of building materials and building elements 'all complement the regulatory review process' (Horrigan 2009:33) and demonstration projects are operationalising the principles into practice.

In a similar manner, in Canada and the United States there is recognition of the merits of integrating sustainability with the preservation of historic built assets: 'There is an increasing dialogue between historic preservation and green building advocates with the aim of defining both the areas of conflict and congruence between the two design approaches.' (Horrigan 2009:34) Similarly, the need for rating tools to expand to incorporate 'more social and cultural metrics' is reaffirmed by Horrigan's investigations in the field.

\section{Summary and conclusion}

Australia has been very tardy in both its formal policy approaches and operational practice responses to issues associated with the reduction of carbon pollution in the atmosphere, which many recognise as a potential cause of rapid and severe global climate change. In recent years, whilst there has been extensive enquiry into the role of built assets in the context of their impact on resource demand and on emissions in construction and in use, there has as yet been little investigation of the contribution of heritage property to the discussion.

Given this context, this paper has attempted to establish some of the aspects relating to value ascribed to heritage property and its management in respect of community perspectives and economic considerations and then to introduce consideration of heritage property from an environmental stance. The paper has identified and discussed how built heritage and associated elements of its management are defined and has considered the roles of community, state and national organisations which contribute to supporting this much valued component of Australia's identity. Societal, economic and environmental paradigms have been used to frame the discussion and the timeliness of further enquiry into the environmental component has been established. 
Whilst recent research in to the assessment of built heritage from a resource use perspective is only now emerging, it is pertinent - in the context of the values which heritage represents in our society - that the intention of much of the property we now value for its durability and timelessness was in fact constructed with those very same aims of sustainability which our contemporary society is pursuing with great zeal bringing the concept of the stewardship to mind. Stewardship is defined by the United States' EPA (Wikipedia 2010) as 'the responsibility for environmental quality shared by all those whose actions affect the environment'. It thereby bestows a responsibility on all human kind and with the role of steward defined by the OED (1976) as '1. Person entrusted with management of another's property, esp. (sic) manager of great house or estate', there remains much to investigate and the past should be employed to inform the present as such concerns are relevant to our future as they were to our past.

\section{References}

Abelson, P 2001, Economics of heritage listings part A: Valuing the public benefits of heritage listing of commercial buildings, NSW Heritage Office, Sydney.

Allen Consulting Group, 2005, Valuing the priceless: The value of heritage protection in Australia, Research report 2, Prepared for the Heritage Chairs and Officials of Australia and New Zealand, Sydney.

Aplin, G 2002, Heritage - identification, conservation and management, OUP, Melbourne.

Armitage, LA and Yau, Y 2008, 'Heritage protection in the built environment in Hong Kong and Queensland: a cross cultural comparison', ch.11, in Khadpekar NR (ed), Urban Revitalisation perspectives and initiatives, Icfai University Press, Hyderabad, India, pp.137-152.

Asabere, PK and Huffman, FE 1994, 'Historic designation and residential market values', The Appraisal Journal, vol. 62, no. 3, pp. 396-401.

Asabere, P.K, Huffman, FE and Mehdian, S 1994, 'The adverse impacts of local historic designation: The case of small apartment buildings in Philadelphia', Journal of Real Estate Finance and Economics, vol. 8, no. 3, pp. 225-234.

Ashworth, GJ 2002, 'Conservation designation and the revaluation of property: The risk of heritage innovation', International Journal of Heritage Studies, vol. 8, no. 1, pp. 9-23.

Australia ICOMOS (International Council on Monuments and Sites) 1999, The Burra charter: The Australia International Council on Monuments and Sites charter for places of cultural significance 1999, Australia ICOMOS, Sydney.

Australian Bureau of Statistics (ABS) 2009, 4172.0 - Arts and culture in Australia: A statistical overview: International cultural tourism, accessed 8 October 2010.

Australian Bureau of Statistics (ABS) 2009a, 4172.0 - Arts and culture in Australia: A statistical overview: Domestic cultural tourism, accessed 8 October 2010. 
Australian Government Productivity Commission 2006, Conservation of Australia's historic heritage places, Australian Government Productivity Commission, Melbourne.

Australian Heritage Commission Act 1975 (Cth)

Australian Property Institute 2008, Australia and New Zealand Valuation and property standards, Australian Property Institute, Deakin, ACT.

Brown, S 2004, 'How to extract cash from old bricks', The Estates Gazette, 4 Sept, pp. 112-113.

Carbon Trust 2008, Low carbon refurbishment of buildings, Carbon Trust, London, accessed 12 October 2010 http://www.carbontrust.co.uk/Publications/pages/publicationdetail.aspx?id=CTV038

Clark, DE and Herrin, WE 1997, 'Historical preservation and home sale prices: Evidence from the Sacramento housing market', The Review of Regional Studies, vol. 27, no. 1, pp. 29-48.

Coulson, NE and Lahr, ML 2005, 'Gracing the land of Elvis and Beale Street: Historic designation and property values in Memphis', Real Estate Economics, vol. 33, no. 3, pp. 487-507.

Deodhar, V 2004, 'Does the housing market value heritage? Some empirical evidence', Macquarie Economics Research Paper, no. 3, accessed 10 October 2010.

http://www.heritage.wa.gov.au/assets/files/LG_publications/SyndeyResearchHousingMarket.pdf

Dixon, T 2009, Property in the economy - Sustainability and corporate real estate, RICS, London.

Dominy, C 2001, The economics of heritage listings: The impacts of heritage requirements on the financial viability of individual development proposals. University of Western Sydney, Sydney.

Environment Protection and Biodiversity Conservation Act 1999 (Cth)

Environmental Protection Authority Western Australia (EPAWA) 2007, State of the environment report: Western Australia, Environmental Protection Authority, Perth, WA, accessed Feb. 2008. http://www.soe.wa.gov.au/report/heritage.html.

Ford, DA 1989, 'The effect of historic district registration on single family home prices', ARUEA Journal, vol. 17, no. 3, pp. 353-342.

Garnaut, R 2008, The Garnaut Climate Change Review: Final Report, Commonwealth of Australia, accessed 12 October 2010.

http://www.garnautreview.org.au/CA25734E0016A131/WebObj/ETSDiscussionPaper_ExecutiveSum mary/\$File/ETS\%20Discussion\%20Paper Executive\%20Summary.pdf

Gore, A 2006, An Inconvenient Truth, motion picture, Lawrence Bender Productions and Participant Productions, distributed by Paramount Classics, United States.

Heritage Council of Western Australia (HCWA) and Tourism Western Australia 2005, A heritage tourism strategy for Western Australia: Background paper, Heritage Council of Western Australia, Perth.

Horrigan, K 2009, A study of international approaches to the relationship between heritage conservation and sustainability, final report of 2009 Churchill Fellowship, Winston Churchill Memorial Trust of Australia., accessed $12^{\text {th }}$ October 2010 www.churchilltrust.com.au/site_media/.../Horrigan_Kenneth_2009.pdf 
International Valuation Standards Committee 2007, International valuation standards, IVGN No. 15 Valuation of historic property, International Valuation Standards Committee, London.

InterSector 2006 'Boost for heritage-based tourism', InterSector, vol.12, no. 9, pp. 13-14, accessed May, 2008. http://www.intersector.wa.gov.au.

Irons, J 2008, 'Heritage listing and property value', dissertation presented to the Queensland University of Technology School of Urban Development in partial fulfilment of the requirements for a Master of Property Economics, Queensland University of Technology, Brisbane.

Irons, J and Armitage, LA 2010, 'Heritage listing and property value: an Australian perspective of the legislative framework', paper presented to the European Real Estate Society Conference, Milan, $23^{\text {rd }}$ to $26^{\text {th }}$ June 2010.

Nahkies, B 2002, 'Heritage protection - redefining highest and best use', paper presented to the $8^{\text {th }}$ annual Pacific Rim Real Estate Society Conference,18-21 January, Christchurch, New Zealand.

New South Wales Heritage Office 2002, Local government heritage guidelines, NSW Heritage Office, Sydney.

Quigley, J 1987, Incentives for heritage conservation and the effect of heritage listing on the value of residential properties, South Australian Institute of Technology, Adelaide.

RICS 2009, Valuing heritage assets: Final report of a research project examining the case for the valuation of heritage assets, Royal Institution of Chartered Surveyors, London.

Rypkema, DD 2005, The economics of historic preservation: a community leader's guide, National Trust for Historic Preservation, Washington DC, USA.

Scanlon, K, Edge A and Willmott, T 1994, The listing of buildings: The effect on value, RICS, London.

Schaeffer, P V and Millerick C A 1991, 'The impact of historic district designation on property values: An empirical study', The Economic Development Quarterly, vol.5, no. 2, pp. 301-331.

Shipley, R. 2000, 'Heritage designation and property values: Is there an effect?', International Journal of Heritage Studies, vol. 6, no. 1, pp. 83-100.

Stern, N 2006, The economics of climate change, Cambridge University Press, Cambridge.

Wikipedia 2010, accessed 19 October 2010, http://en.wikipedia.org/wiki/Stewardship 